\title{
Foetal Wastage Among Ruminants Slaughtered at the Abattoir in Gwagwalada, FCT, Nigeria
}

\author{
*Obudu C. E., Ubah S. A., Erondu V. C., and Columbus P. K \\ Dept. of Theriogenology, Faculty of Veterinary Medicine, \\ University of Abuja, Gwagwalada, Nigeria \\ DOI:10.36108/jvbs/8102.10.0170
}

\begin{abstract}
There is a chronic deficiency in the animal protein content of the diets of people in developing countries, including Nigeria. This has been attributed to low productivity of indigenous breeds of livestock, inadequate feed supplies, diseases and recently, climate change. However, foetal losses from slaughtered food animals have been identified as a potential source of animal protein loss but its overall negative impact on the national economy has not been evaluated. This study was therefore carried out to draw attention about the consequences of the practice and to proffer some recommendations. A five - month study was carried out to investigate the incidence of foetal wastage in ruminants slaughtered at the Gwagwalada abattoir in the Federal Capital Territory (FCT), Abuja, Nigeria as well as its economic implications. Results indicated that the incidence was 29.02\%, 24.9\% and 7.68\% for cattle, sheep and goats respectively. Most of the wastage occurred in the first and second trimesters of pregnancy, while the total financial loss from the 260 foetuses recorded in the study was put at about N10.5 million. There is therefore the need for a more detailed and comprehensive examination offemale animals prior to slaughter. Those diagnosed to be pregnant should be purchased and nurtured by relevant government agencies until delivery and the owners compensated. In addition, public enlightenment campaigns discouraging farmers from slaughtering obviously pregnant animals should be mounted, while violators should be made to payfines.
\end{abstract}

Key words: Abattoir, Foetus, Ruminants, Nigeria

*Corresponding email: christopher.obudu@uniabuja.edu.ng Tel: +234 (0)8098108077

This Paper was accepted on 16th November, 2017 and published 24th April, 2018 


\section{INTRODUCTION}

Livestock play important socio - cultural and economic roles in the lives of people in sub Saharan Africa, including Nigeria and is one of the fastest growing of the agricultural subsectors in many developing countries [1].This growth is driven by the rapidly increasing demand for livestock products, due to population growth, urbanisation and increasing incomes in developing countries [2]. Livestock acquisition as a pathway out of poverty has been documented[3]in western Kenya. They provide traction mainly in irrigated, densely populated areas, and allow cropping in these places. They also provide nutrients in the form of manure, a key resource, particularly for the mixed farming systems of sub-Saharan Africa. In addition, livestock serve as financial instruments, by providing households with an alternative for storing savings or accumulated capital, and they can be sold and transformed into cash as needed and so provide an instrument of liquidity and insurance. For some poorer households, livestock can provide a means of income diversification to help deal with times of stress $[3,4]$. In many parts of Africa, social relationships are partly defined in relation to livestock, and the size of a household's livestock holding may confer considerable social importance on it. The sharing of livestock with others is often a means to create or strengthen social relationships, through their use as dowry or bride price, as allocations to other family members and as loans [5]. Social status in livestock-based communities is often associated with leadership and access to (and authority over) natural, physical and financial resources.

Nigeria is presently trailing behind in terms of livestock production and per capita animal protein consumption [6]. There are about 13.9 million cattle, 22.1 million sheep and34.5 million goats in Nigeria while the mean animal protein intake (meat, milk, fish and eggs) per caput per day has been estimated at about $14.85 \mathrm{~g}$, which is much lower than the North American and European averages of $38.3 \mathrm{~g}$ and $27.3 \mathrm{~g}$ respectively [7]. The growth rate of livestock production estimated at between $0.8 \%$ and $2.9 \%$ per annum is too slow to cope with the per capita requirements of the Nigerian population of over 170 million people and an estimated growth rate of about $3.5 \%$ per annum [8]. This deficit in livestock production as well as attractive profit in the meat business has led to the unhealthy practice of slaughter of breeding stock and pregnant animals in African, including Nigerian abattoirs [9]. The slaughter of pregnant livestock will no doubt worsen the already precarious supply of animal protein to the populace $[10,11]$. Foetal losses through the slaughter of pregnant cows has received increasing attention over the past few years; however the empirical evidence of the effect of the practice on beef production is limited. In addition, previous studies mostly concentrated on cattle foetuses. This study was therefore embarked upon to investigate the incidence of fetal wastage in all ruminants (cattle, sheep and goats) as well as to estimate the financial 
losses associated with the practice.

\section{MATERIALSAND METHODS}

\section{Study Location}

This study was conducted at Gwagwalada abattoir, Gwagwalada Area Council, Abuja, Federal Capital Territory (FCT),Nigeria. The study location is between latitude $8^{\circ}$ and $9^{\circ} 25^{\prime}$ North of the equator and longitude $6^{\circ} 45^{\prime}$ and $7^{\circ} 45^{\prime}$ East of Greenwich Meridian. The territory covers an area of $1,043 \mathrm{~km}$ and falls within the semi-seasonal equatorial climate zone with associated contrasting wet and dry periods. The rainy season begins in April and ends in October when day time temperatures reach $28^{\circ} \mathrm{C}$ to $30^{\circ} \mathrm{C}$ and night time of $22^{\circ} \mathrm{C}$ to $23^{\circ} \mathrm{C}$. During the dry season day time temperature can soar as high as $40^{\circ} \mathrm{C}$ and night time temperature can drop as low as $12^{\circ} \mathrm{C}$. The high altitude and undulating terrain of the FCT acts as a moderating influence on the weather of the territory. It is therefore suitable for livestock production and as a transit camp for herdsmen as they move their stock to the southern part of the country for grazing or sale. FCT falls within the Guinea Forest -Savanna Mosaic zone of the West African sub-region.

\section{Slaughter Procedure}

An average of 20 cattle, 30 goats and 5 sheep were slaughtered per day during the study period. The animals were bought from near-by livestock markets such as Dei-Dei in the FCT, Lambatta in Niger State as well as Jere in Kaduna State. Cattle for slaughter were brought in the previous evening and kept in a lairage, while goats and sheep were brought in the morning of slaughter. Slaughtering was done using the Halal method which consists of a swift, deep incision with a sharp knife on the throat, cutting the jugular veins and carotid arteries of both sides but leaving the spinal cord intact. Thereafter the carcasses were flayed, cut into parts, with the liver, lungs and the heart set apart in readiness for inspection by the animal health worker. Most of the goats were slaughtered and roasted for dehairing while the sheep were flayed.

\section{Data Collection}

The study covered a period of five months from January- May 2015. Sampling was done from Monday to Saturday and pregnant uteri were established by visual examination and dissection. The total number of cattle, sheep and goats slaughtered was recorded and the number of male and female animals was noted. After slaughter the uteri were exteriorized and dissected and the number of fetuses recovered for each day was recorded.

\section{Handling of samples and Sexing of foetuses}

Proper gloving of the hand was done before data collection to avoid zoonotic transmission of diseases. The sexes of the foetuses were determined by grossly examining the external genitalia. The females had invaginations which indicated the developing vagina, while the males showed evidence of a developing scrotal sac. However, the sex of few of the foetuses that were less than one month of age was not determined due to the underdevelopment of the organs. 


\section{Foetal wastage at the Gwagwalada Abattoir}

\section{Aging of foetuses}

The ages of foetuses wasted during the study period was calculated by measuring the crown - rump length using the following formula by [9]:

Age of calf $(\mathrm{X})$ in days $=2.5(\mathrm{Y}+21)$

$\mathrm{Y}=$ crown-rump length in centimetres, and

21 ; is a mathematical constant.

To measure the crown-rump length, the foetuses were laid on lateral recumbency and measured from the middle of the forehead to the base of the tail, using a measuring tape. Any value obtained was then substituted for $Y$ in the formula above, to give the estimated age of the foetus in days. This was then converted to months by dividing the result by 31 and the answer grouped into one of the trimesters of the cow's gestational age, since the gestational period of the cow is nine months.

For example, if the crown -rump length of a foetus is $38 \mathrm{~cm}$, to calculate the age of the age of the foetus in months we use the formula $\mathrm{X}=$ $2.5(\mathrm{Y}+21)$ for a calf, where

$\mathrm{Y}=38 \mathrm{~cm}$

Therefore $X=2.5(38+21)$

$\mathrm{X}=2.5(59)$

$\mathrm{X}=147.5$ days

\section{Calculation of the incidence rate}

The incidence rate was calculated by dividing the total number of fetuses recovered over a period of time by the total number of female animals slaughtered and multiplied by 100 as described by [10].

\section{Data Analysis}

The data generated from this study were subjected to analysis of variance using species as factor, and simple descriptive statistics (means and percentage) were also used to describe other relevant information.

\section{RESULTS}

A total of 4,087 ruminants were slaughtered at the Gwagwalada abattoir during the study period (January - May 2015). Out of these, 1,684 were cattle, 1,934 goats and 469 sheep. Table I shows the monthly and sex distribution of cattle slaughtered as well as the number of foetuses recovered per month, while Tables II and III show the results for goats and sheep respectively. Table IV shows the monthly average of the ruminant species slaughtered as well as the monthly incidence of foetal wastage, while Table $\mathrm{V}$ shows the sex distribution of foetuses recovered at the abattoir over the five - month study period.

Figure 1 represents the stage of gestation at which foetuses are lost due to slaughter of pregnant cows, does and ewes in Gwagwalada abattoir. 


\section{Foetal wastage at the Gwagwalada Abattoir}

Table I: Monthly distribution of cattle slaughtered in Gwagwalada, showing sex distribution and incidence of wasted foetuses.

\begin{tabular}{lccccc}
\hline Month & $\begin{array}{c}\text { Total Cattle } \\
\text { Slaughtered }\end{array}$ & $\begin{array}{c}\text { Bulls } \\
\text { slaughtered }\end{array}$ & $\begin{array}{c}\text { Cows } \\
\text { slaughtered }\end{array}$ & Fetuses & Incidence (\%) \\
\hline Jan. & 346 & 258 & 88 & 30 & 34.09 \\
Feb. & 298 & 238 & 60 & 11 & 18.33 \\
March & 402 & 327 & 75 & 29 & 38.67 \\
April & 259 & 208 & 51 & 19 & 37.25 \\
May & 379 & 305 & 74 & 12 & 16.22 \\
\hline Total & 1684 & 1336 & 348 & 101 & 29.02 \\
\hline
\end{tabular}

Table II: Monthly distribution of goats slaughtered at the Gwagwalada abattoir

\begin{tabular}{lccccc}
\hline Month & $\begin{array}{c}\text { Total Goats } \\
\text { Slaughtered }\end{array}$ & $\begin{array}{l}\text { Bucks } \\
\text { Slaughtered }\end{array}$ & $\begin{array}{c}\text { Does } \\
\text { Slaughtered }\end{array}$ & Fetuses & Incidence(\%) \\
\hline Jan. & 410 & 162 & 248 & 25 & 10.08 \\
Feb. & 367 & 134 & 233 & 20 & 8.58 \\
March & 322 & 77 & 245 & 27 & 11.02 \\
April & 435 & 123 & 312 & 17 & 5.45 \\
May & 400 & 150 & 250 & 10 & 4 \\
\hline Total & 1934 & 646 & 128899 & & 7.68 \\
\end{tabular}

Table III: Monthly distribution of sheep slaughtered at the Gwagwalada abattoir

\begin{tabular}{lcclcc}
\hline Month & Total Sheep & Rams & Ewes & \\
& Slaughtered & Slaughtered & Slaughtered & Fetuses (n) & Incidence(\%) \\
\hline Jan. & 66 & 35 & 31 & 5 & 16.13 \\
Feb. & 86 & 45 & 41 & 9 & 21.95 \\
March & 100 & 46 & 54 & 12 & 22.22 \\
April & 118 & 52 & 66 & 17 & 25.76 \\
May & 99 & 50 & 49 & 17 & 34.69 \\
\hline Total & 469 & 228 & 241 & 60 & 24.90
\end{tabular}




\section{Foetal wastage at the Gwagwalada Abattoir}

Table IV: Monthly average of ruminants slaughtered at Gwagwalada abattoir

\begin{tabular}{lccc}
\hline & Cattle & Goats & Sheep \\
\hline Total no. of ruminants & & & \\
slaughtered & $336.8 \pm 26.15^{\mathrm{a}}$ & $386.8 \pm 19.53^{\mathrm{a}}$ & $93.8 \pm 8.62^{\mathrm{b}}$ \\
No. of males & $267.2 \pm 21.73^{\mathrm{a}}$ & $129.2 \pm 14.65^{\mathrm{b}}$ & $45.6 \pm 2.94^{\mathrm{b}}$ \\
No. of females & $69.6 \pm 6.42^{\mathrm{a}}$ & $257.6 \pm 13.92^{\mathrm{b}}$ & $48.2 \pm 5.91^{\mathrm{a}}$ \\
Total no. fetuses & $20.2 \pm 4.02^{\mathrm{a}}$ & $19.8 \pm 3.02^{\mathrm{a}}$ & $12.00 \pm 2.32^{\mathrm{a}}$ \\
\% incidence of fetal & & \\
wastage & $28.91 \pm 4.82^{\mathrm{a}}$ & $7.83 \pm 1.34^{\mathrm{b}}$ & $20.30 \pm 3.02^{\mathrm{ab}}$ \\
& & \\
\hline & & \\
\hline Note: a,b,c means in the same row having different superscripts differed significantly
\end{tabular}

Table V: Monthly average sex distribution of all ruminant (cattle, goat and sheep) fetuses recorded in Gwagwalada abattoir.

\begin{tabular}{llll}
\hline & Cattle & Goats & Sheep \\
\hline Total number of fetuses & $20.2 \pm 4.02$ & $19.8 \pm 3.02$ & $12.00 \pm 2.32$ \\
Male fetuses & $11.6(57.42 \%)$ & $10.6(53.54 \%)$ & $7.6(63.33 \%)$ \\
Female fetuses & $8.6(42.58 \%)$ & $9.2(46.46 \%)$ & $4.4(36.67 \%)$ \\
\hline
\end{tabular}

Note:Values in bracket column-wise are percentages of the monthly total while those in the row are species total of fetal wastage.

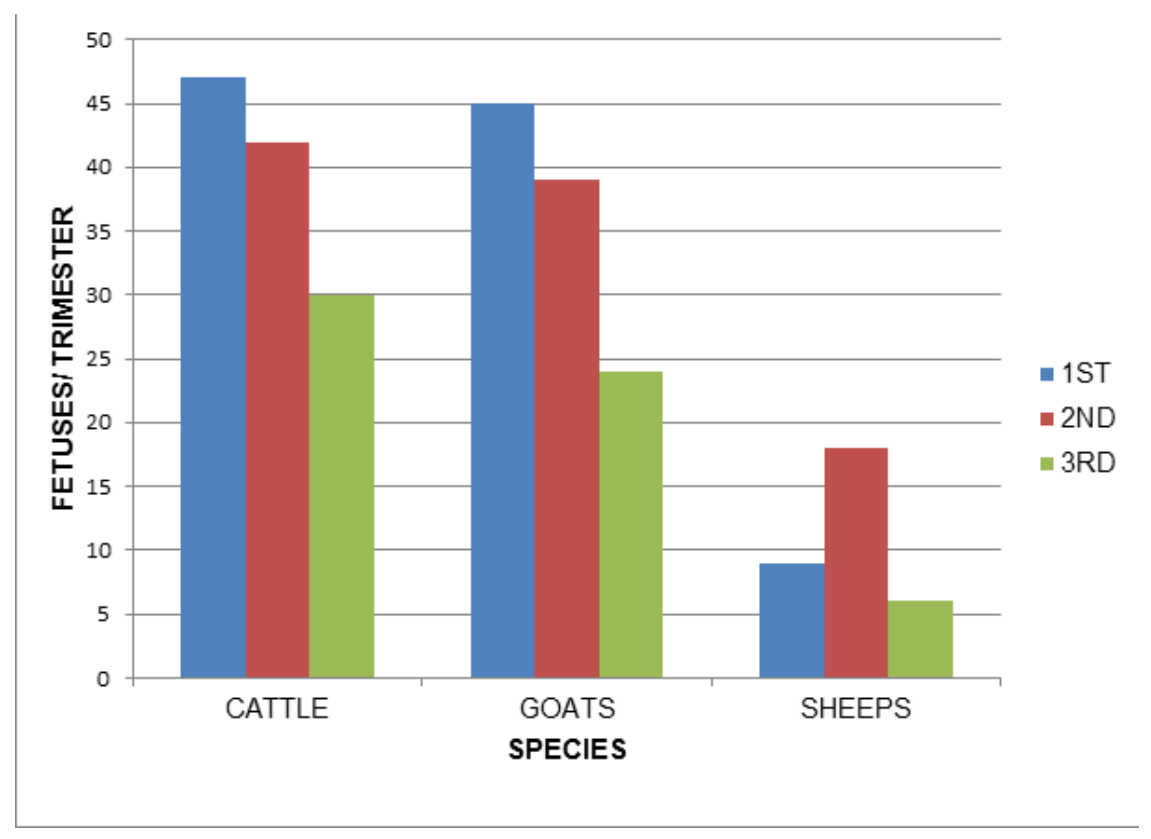

Figure 1: Total number of fetuses wasted in each trimester between January - May, 2015 


\section{RESULTS AND DISCUSSION}

The result showed that there was a significant difference in the total number of different species of ruminants slaughtered at Gwagwalada abattoir $(\mathrm{p}=\mathrm{0.000})$, with goats being the most, followed by cattle and sheep as shown in Table IV. This might be due to the fact that they can tolerate and adapt to a wide range of climatic conditions, especially during periods of feed scarcity [12]. Goats are also easier to manage under the free range system since their diet is usually not supplemented under the system. They are liquid assets compared to sheep and cattle because of their low value or price in the market and their meat is well-cherished by most people across various ethnic groups in the country. Sheep are generally less popular as a source of meat, except during Islamic festivities which did not fall within the study period. Cattle, on the other hand, are quite expensive to maintain, hence most butchers prefer to go for goats as they are low income earners and most of them operate their businesses of meat processing and handling locally and on a small-scale. However, there seemed to be no significant difference between cattle and goats slaughtered $(p=0.207)$, which is in agreement with an earlier report by [14]. Out of 1,684 cattle slaughtered 1,336 (79\%) were bulls as shown in Table I; out of 1,934 goats slaughtered 646 (33\%) were bucks (Table II) and out of 469 sheep slaughtered 228(47\%) were rams (Table III). There was a significant difference between the number of males slaughtered of the various species $(p=0.00)$. However, the number of billy goats and rams had no significant difference $(\mathrm{p}=0.06)$ with more bulls being slaughtered on the average (267.20 \pm 21.73$)$.This is in contrast to findings by[15], who reported that in Cameroon most of the cattle slaughtered in Bamenda municipal abattoir were females.

Out of 1,684 cattle slaughtered, 348 (21\%) where cows (Table I), out of 1,934 goats slaughtered 1,288 (67\%) were does (Table III) while out of the 469 sheep slaughtered $241(53 \%)$ were ewes, hence there was a significant difference between the number of females slaughtered $(p=0.00)$. However, there was no significant difference between slaughtered cows and ewes $(p=0.285)$ with more does slaughtered on the average $(257.6 \pm 13.92)$. The result portends great danger to the reproductive efficiency of the goat population, as more females are required for reproduction than males. This agrees with the assertion of [16], who reported that the act of slaughtering female animals is a deterrent to animal production. Conversation with the butchers revealed that male goats and rams are more priced than the females which are cheaper and readily available for purchase.

The study also revealed an incidence of $29.02 \%$ for cattle, $7.68 \%$ for goats and $24.90 \%$ for sheep as shown in Table I, II and III. There was a significant difference in the incidence of fetal wastage amongst the various species of livestock slaughtered $(\mathrm{p}=0.02)$, with incidence between cattle and sheep showing no significant difference $(p=0.594)$. The incidence of foetal wastage between goats and cattle was highly significant $(\mathrm{p}=0.02)$ while that of goats and sheep had no significant 


\section{Foetal wastage at the Gwagwalada Abattoir}

difference $(\mathrm{p}=0.13)$.

More male foetuses were wasted during the study period, which agrees with an earlier report by [16], that out of the $75 \%$ foetuses obtained at Nsukka zonal abattoir, 50\% were males while $25 \%$ were females. From the data analyzed, it was observed that a higher number of foetal wastage in cattle and goats occurred in first and second trimester respectively while the lowest wastage occurred in the third trimester. This is in conformity with what was reported by [18] from a retrospective study in an abattoir in North western Nigeria. The reason there were more foetuses in the first and second trimesters might be because at this stage of pregnancy, the animals do not appear pregnant by their owners' visual examination hence they are assumed to be non pregnant and can be sold for slaughter; whereas at the third trimester, the abdomen is conspicuously distended and the udder swollen. This leaves the owner with the decision not to sell off such animals in most cases.

The total financial losses over the five months study period due to wastage of 349 foetuses can be estimated as follows;

The estimated cost of adult cattle in Gwagwalada is between N80, 000to N100, 000 (average of N90,000).

Cattle foetuses wasted were 101; therefore the total amount lost from wasting 101 foetuses in five months was N 9,090,000 $(101 \times$ N90, 000) Similarly, the cost of a mature goat and sheep is between N6000 - 12000, a total of 99 foetuses were wasted from goats while 60 foetuses were wasted from sheep. This will give a total of 159 foetuses. If the average cost of either a sheep or goat is N9, 000 the total cost of the wastage would be N1, 431,000. This will amount to a grand total of N10, 521,000 or > US\$50,000 (1US\$ $\approx N 200)$ within the five months studied. The high incidence of foetal wastage encountered poses a significant threat to both livestock production and the economy of the country. However, the incidence is lower than that reported by [19]. This may be due to the difference in the duration of the study, species studied, locality and the price of livestock in the different parts of the country. Cattle are more expensive in the North Central part of the country than in the North Western part.

In conclusion, the incidence of foetal wastage in ruminants slaughtered at the Gwagwalada abattoir is high. Slaughtering of pregnant livestock leads to loss of fertile dams that would have actively increased the livestock population of Nigeria and improved the animal protein available to the citizenry. Slaughtering of pregnant animals for meat purposes is unethical and is contrary to the rules of slaughter under which only unproductive, infertile, sterile, geriatric animals and those in severe pain are allowed to be slaughtered [19].This ugly practice also frustrates the scientific endeavours of geneticists, nutritionists and livestock breeders working for the propagation of various animal species [19]. If this trend is not controlled, the national livestock industry will be highly depleted within the next decade.

In Nigeria, a law regulating meat inspection has been in existence and was amended in 1966 


\section{Foetal wastage at the Gwagwalada Abattoir}

to conform to W.H.O. directives of 1962, that veterinarians all over the world should be in control of meat inspection and that such duty be transferred to the Veterinary Department. This law (the Meat Edict of 1968) took effect in 1968 in the northern states but was amended in 1975 (in Borno state) due to the fact that many pregnant animals were being slaughtered. However, despite the provisions of this law, which legally outlawed the slaughter of pregnant animals nearly 4 decades ago, the practice has continued to thrive unabated. Although, this problem is a global phenomenon [20], in some countries, the magnitude is minimized by strict laws $[20,21$, 22]. In the USA for instance, slaughter of pregnant cows is not allowed by law; the only condition being emergencies associated with infertility, where the cow is expected to be euthanized [23, 24]. Anything short of this is considered as cruelty to the animal [21] and the culprits must pay fines [25, 26]. For example, in the USA, fines of US\$ 1,000 to US\$10,000 may be charged, with the chances of suspension or revocation of the offending abattoir operator's license for cruelty on livestock as well as maternal slaughter of animals at slaughterhouses [26]. In Sri Lanka, a sum of one hundred thousand Sri Lankan Rupee (Rs 100,000.00) approximately US\$ 900 is paid as fine for similar offences [25]. However in Nigeria, the level of enforcement of this law is low, associated with low levels of penalties fixed for such offences [28]. It is therefore high time that these issues were addressed by the appropriate regulatory authorities in order to prevent such incidences and boost the development of the livestock subsector.

From the foregoing, the following recommendations are hereby proposed:

1. Veterinary structures and services especially as they relate to ante-mortem examination in our abattoirs must be put in place and strengthened.

2. Public enlightenment campaigns should be carried out using the mass media towards enlightening producers about the seasonal breeding patterns of food animals in order to avoid disposing of them during the calving season as well as the implications of slaughtering pregnant cows.

3. Law enforcement agents should be deployed to re-enforce the laws prohibiting the slaughter of pregnant animals in the abattoirs and a stricter punishment for offenders as obtained in developed countries like the USA.

4. Routine veterinary checks, including pregnancy diagnosis using portable ultrasound scanners and other techniques should be conducted by Veterinarians at animal control posts and abattoirs which should be established in all Local Government Areas in Nigeria. 
Foetal wastage at the Gwagwalada Abattoir

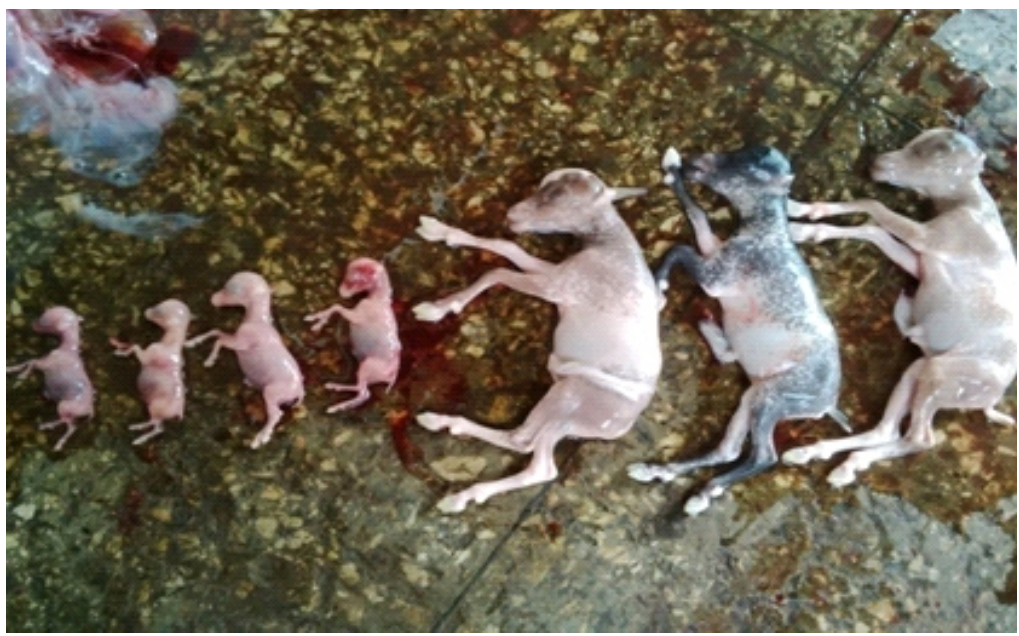

Plate 1: Goat foetuses at different trimesters of gestation recorded on the same day

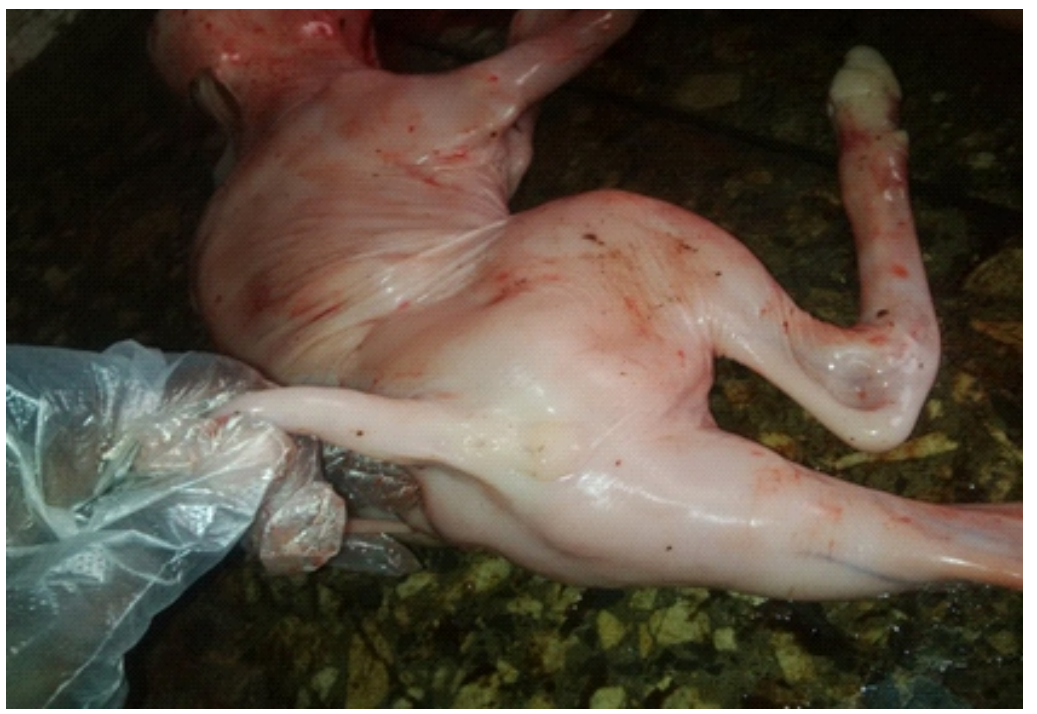

Plate2: Cow foetus. Note the presence of the genital ridge which would later develop into the vulva and vagina

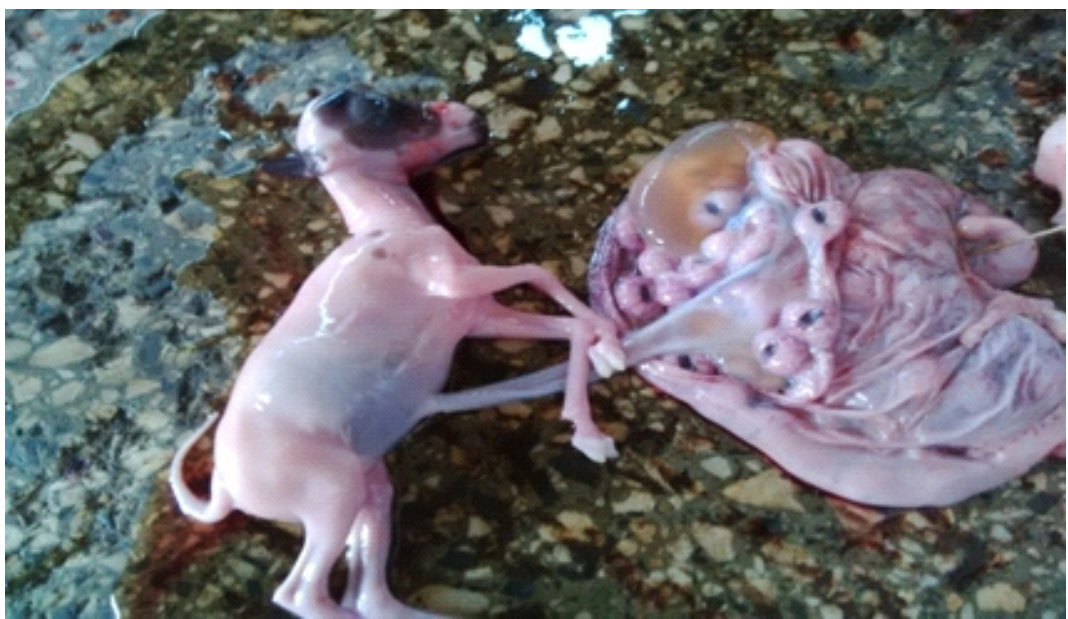

Plate 3: Sheep fetus at second trimester of pregnancy 


\section{Foetal wastage at the Gwagwalada Abattoir}

\section{REFERENCES}

1. World Bank (WB) (2009). Minding the stock: bringing public policy to bear on livestock sector development. Report no. 44010-GLB. Washington, DC.

2. Delgado C. and Mcgilloway D. A. (2005). Rising demand for meat and milk in developing countries: implications for grasslands-based livestock production. In Grassland: a global resource (ed. McGilloway D. A.), The Netherlands: Wageningen Academic Publishers, Pp. 29-39.

3. Kristjanson P., Krishna A., Radeny M., and Nindo W.(2004). Pathways out of poverty in western Kenya and the role of livestock. PPLPI Working Paper No. 14. Rome, Italy: FAO.

4. Mubi, A.A., Michika, S. A., and Midau, A. (2013).Cattle marketing in Mubi Area of Adamawa State, Nigeria. Agricultural and Biology Journal of North America 4 (3):199-198

5. Kitalyi A., Mtenga L., Morton J. U., Mcleod A., Thornton P., Dorward A., and Saadullah M. (2005). Why keep livestock if you are poor? In Livestock and wealth creation: improving the husbandry of animals kept by resourcepoor people in developing countries (eds Owen E., Kitalyi A., Jayasuriay N., Smith T.), Nottingham, UK: Nottingham University Press, Pp. $13-27$.

6. Chaudhari S. U. R and Bokko, P B.(2000). Reproductive status, pregnancy wastage and incidence of gross genital abnormalities in cows slaughtered at the Maiduguri abattoir, Nigeria. Pakistan Veterinary Journal 20: $182-184$
7. Abdullahi, A.K. (1985). The Slaughtering of Pregnant Cows. PhD. Thesis, University of Nottingham, Leicestershire UK.

8. Abdulkadir, U., Jiya, E.Z., and Kosu, S.A. (2008). Survey of Foetal Wastages: A case study of Makurdi abattoir in Benue State from 1997 to 2002. Pakistan Journal of Nutrition, 7(3): 450-452.

9. Harris, R.M., Snyder, B.G., and Meyer, R.(1983) TheRelationship of Bovine Crown-Rump Measurement to Fetal Age. Agri-pracitce. 4(6):16-22.

10. Odeh, S., Dawuda, P. M., Oyedipe, E. O. and Obande, G. E (2015). Incidence of Foetal Wastage in Slaughtered Cattle at Wurukum Abattoir, Makurdi, Benue State. Vom Journal of Veterinary Science, 10: $41-50$

11. Zahraddeen D. (2006). Studies on reproductive performance and milk productivity of goats in Bauchi. An unpublished Ph.D. Thesis, Animal Production Programme, Abubakar Tafawa Balewa University, Bauchi, Nigeria, pp210.

12. Butswat, I. S. R. and Bello M. (2002). "Contribution of Different Livestock Species as Sources of Meat in Bauchi", Nigerian Journal of Animal Production, 29 (2):207-216.

13. Tolumn, A. (2004). Calves lost through pregnant cows slaughtering: A particular case in Yaoundé Abattoir ( C a m e roon) " Tropical Veterinarian.37:62-75.

14. Ayodele A.O., Fadiyimu, A.A, Folorunsho, O.R and Olowu, O.P.A (2003). Foetal Wastages through the 
Slaughtering of Pregnant Cows in Akure Abattoir. Proceedings of 28th Conference of Nigeria Society of Animal Production 2: 45-51.

15. Onu, J. E., and Obudu, C. E. (2002) Foetal Wastages in Cattle, a Retrospective Study in Nsukka Zonal Abattoir. In: Proceedings ofthe 36th Annual Congress forNigerian Veterinary Medical Association, Kaduna, Pp. 19-22.

16. Ngbede, E.O., Hena, S.A., Oguntoye, O.O., Tarhyel, R., and Bulus, C.(2012). Bovine Foetal Wastage and Its Economic Implication: a six-year (2003 - 2008) Retrospective Study in an Abattoir in Northwestern Nigeria. Science Journal of Veterinary Advances, 1(2): 42-46.

17. Khan M. Z., and Khan A (1989). Frequency of Pregnant Animals Slaughtered at Faisalabad Abattoir. Journal Islamic Academy Science, 2:82.

18. Fayemi, P.O., and Muchenje, V. (2013). Maternal slaughter at abattoirs: history, causes, cases and the meat industry. Springer Plus, 2: 125 . http://www.springerplus.com/content/2 $/ 1 / 125$

19. Riehn, K., Domel, G., Einspanier, A., Gottschalk, J., Hildebrandt, G., Luy, J., and Lucker, E. ( ( 201010$)$. R SchlachtunggraviderRinder- ethische und rechtlicheAspekte (Slaughter of Pregnant Cattle-Ethical and Legal Aspects),90th edn. Deutscher
Fachverlag, Frankfurt am Main, Allemagne (Revue), Pp. 100-106.

20. Singleton, G.E (2010).Guidance for Veterinary Surgeons on the Emergency Slaughter of Cattle. Bri.Cattle Veterinary Association. (BCVA), Edinburgh.

21. Lavi, S. (2007). Animal Laws and the Politics of Life: Slaughterhouse Regulation in Germany (1870) to (1917).Theo Inq Law., 89 (1):10-15.

22. Butterworth, A. (2000). Euthanasia of Large Animals, Veterinary Records, $147(3): 84$

23. Biggs, A., and Blackwell, J.M (2005). Emergency Slaughter, and Changes to the OTM rule. Veterinary Records, 157 (16):490-491.

24. Perera, J. (2006). Animal Welfare Authority Bill handed over to Sri Lankan President. Available on: http://www.buddhistchannel.tv/index Accessed in September 2010.

25. Laura, A. (2010). Conference Committee Endorses Strong Penalties for Humane Slaughter Law Violations. Animal Law Coalition., Available in $\mathrm{http} / / \mathrm{www}$.animallawcoalition.com/fa rm-animalsarticles.

26. Olukole, S.C. (2008). Assessment of Enforcement and Impacts of Two Veterinary Legislations in Oyo State, Nigeria. Nigerian Veterinary Journal, $29(3): 41-47$.

*Obudu C.E., Erondu V.C and Columbus P.K.

(C) Abuja Journal of Veterinary and Biomedical Sciences Vol. 1 April 2018 pp. 53-64 